\title{
Assessment of the Magnitude and Associated Factors of Unmet Need for Family Planning among Women of Reproductive Age Group with Disabilities in Bahir Dar City, Amhara Region, North West Ethiopia
}

\author{
Abel Lule Tessema1, Mekionnen Ayichiluhm Bishaw ${ }^{1}$, Tsion Samuel Bunare ${ }^{2}$ \\ ${ }^{1}$ GAMBY College of Medical Sciences, Bahir Dar, Ethiopia \\ ${ }^{2}$ Felege Hywot Referal Hospitl, Bahir Dar, Ethiopia \\ Email: belolu.tsi@gmail.com, mekachy@yahoo.com, abeleyeye@gmail.com
}

Received 10 January 2015; accepted 30 January 2015; published 4 February 2015

Copyright (C) 2015 by authors and Scientific Research Publishing Inc.

This work is licensed under the Creative Commons Attribution International License (CC BY). http://creativecommons.org/licenses/by/4.0/

\section{(c) (i) 0 pen Access}

\section{Abstract}

The study was conducted to assess the magnitude and associated factors of unmet need for family planning among women of reproductive age group with disabilities who are members of disabled associations in Bahir Dar town. Institution based cross-sectional study was carried out. A total of 337 women of reproductive age group with disabilities were included in the study with simple random sampling. Data were collected through face-to-face interview, coded, cleaned and entered by Epi info 2002 and analyzed with SPSS version 16 computer software. Logistic regression was used to assess possible associations. The magnitude of unmet need for family planning among women with disabilities was $\mathbf{2 4 . 3 \%}$. Women with disabilities in the age group of $25-29$ had $80 \%$ less likely to have unmet need than women above 35 years old. Women with disability who have no education were 11 times more likely to have unmet need than those who have secondary education. Women who desire to have more than 3 children have more likely to have unmet need than those who need to have 1 - 2 children. Unmet need for family planning among women with disabilities was high in Bahir Dar town. Age, Educational status and desired number of children were found to have statistically significant association with unmet need for family planning. Hence, it is important to encourage people with disabilities to attained formal education and the associations should provide short term trainings in accordance with their age group. 
Keywords

\section{Women with Disability, Unmet Need for Family Planning, Bahir Dar City}

\section{Introduction}

The concept of unmet need for family planning refers to fecund women who either wish to postpone the next birth (spacers) or who wish to stop child bearing (limiters) but are not using a contraceptive method [1]. Globally, it is estimated that more than 100 million women in low income countries or about $17 \%$ of all married women, would prefer to avoid pregnancy but are not using any form of family planning [2]. Within the low income regions of the world, about one-fourth of all pregnancies are unintended while an estimated 18 million unsafe abortions take place each year, thereby, contributing to the high maternal mortality and injuries [3]. Approximately 300 million women around the world have mental and physical disabilities. Globally, women make up three-quarters of the disabled people in low and middle income countries, and between 65 and 70 percent of those women live in rural areas. Women with disabilities comprise 10 percent of all women worldwide [4].

Sub-Saharan Africa has the highest fertility rates of any world region, 5.4 births per woman on average, double that of Asia (excluding China) and more than three times that of Europe. Every hour of every day, at least 30 women die from complications of pregnancy and childbirth in sub-Saharan Africa which is about 270,000 deaths every year [5].

Family planning can reduce maternal mortality by reducing the number of pregnancies, the number of abortions, and the proportion of births at high risk. Only 18 percent of married women in sub-Saharan Africa use modern methods of family planning [6].

Demographic health survey (DHS) results in 53 countries reveal that in 16 of 25 countries outside sub-Saharan Africa, unmet need among married women is 15 percent or lower, while only three of 28 sub-Saharan countries have levels that low [7]. An estimated 35 million women in sub-Saharan Africa have an unmet need for family planning. In 28 of 31 countries where unmet need is measured, at least one-fifth of married women ages 15 - 49 have an unmet need for family planning [8]. Unmet need for family planning in Ethiopia was estimated at 35.8\%, 33.8 and 25.3\% in 2000, 2005 and 2011 respectively [9]. In Ethiopia, about 7 million persons are with disabilities [10].

The present study therefore aims at examining both the level of unmet need and factors affecting family planning service utilization in one of the fast growing city of Ethiopia, Bahir Dar.

\section{Methods and Materials}

Institution based cross section study was conducted to assess the prevalence of unmet need for family planning and associated factors among disabled women who are members of disabled associations in Bahir Dar town. A total of 337 women of reproductive age group with disabilities were included in the study using Simple random sampling method. Data were obtained through well designed and pretested questionnaire by face to face interview. Collected data were analyzed using SPSS version 16 computer software.

\section{Result and Discussion}

In this study a total of 337 women with disability aged between 15 - 49 years were included. The response rate was found to be $96.5 \%$. Figure 1 shows ,The Unmet need for family planning among women with disabilities was found to be $24.3 \%$ of which $15.4 \%$ had unmet need for spacing and $8.9 \%$ for limiting childbearing. Table 1 shows, among the participants, majority, $25.2 \%$ were within the age range of $15-19$ years about $84.4 \%$ of the respondents had no education and only $8 \%$ of the respondents are above secondary school. In the forms of disabilities those who are handicapped at the lower limb and handicapped of both limbs, accounted for $39.4 \%$ and $17.8 \%$ respectively. Table 2 shows, nearly $90.5 \%$ of the study participants were heared about family planning. One hundred thirty nine, $42.8 \%$ had been pregnant. Among those, larger proportions of the women, $89.2 \%$ have more than five children and $10.8 \%$ have less than five children. Out of those who had history of pregnancy, $64 \%$ reported that their pregnancy was unintended. Lack of awareness accounts about $38 \%$ and contraceptive failure, 


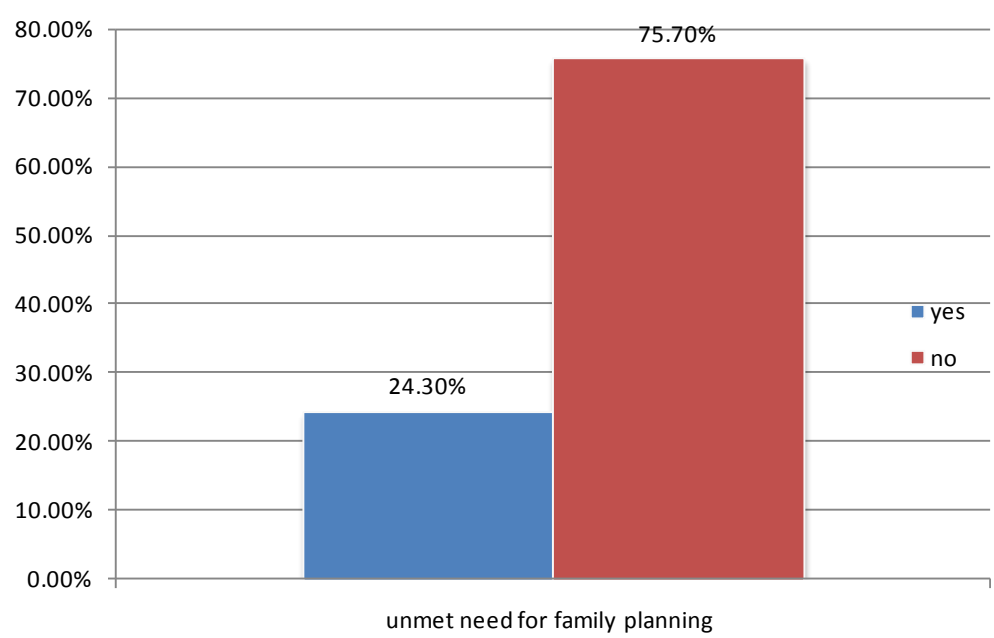

Figure 1. The prevalence of unmet need for family planning among women with disabilities of reproductive age group in Bahir Dar town, Amhara region, Ethiopia, August 2013.

Table 1. Socio demographic characteristics of study participants in Bahir Dar City, Amhara Region, North West Ethiopia, August 2013.

\begin{tabular}{|c|c|c|c|}
\hline Variables & Choices & Frequency & Percentage \\
\hline Age & $\begin{array}{l}15-19 \\
20-24 \\
25-29 \\
30-34 \\
\geq 35\end{array}$ & $\begin{array}{l}82 \\
69 \\
75 \\
38 \\
61\end{array}$ & $\begin{array}{l}25.2 \\
21.2 \\
23.1 \\
11.7 \\
18.8\end{array}$ \\
\hline Marital status & $\begin{array}{l}\text { Married } \\
\text { Single } \\
\text { Have a boyfriend } \\
\text { Divorced } \\
\text { Others }{ }^{\star}\end{array}$ & $\begin{array}{c}134 \\
13 \\
138 \\
24 \\
16\end{array}$ & $\begin{array}{c}41.2 \\
4 \\
42.5 \\
7.4 \\
4.9\end{array}$ \\
\hline Religion & $\begin{array}{l}\text { Orthodox } \\
\text { Muslim } \\
\text { Protestant }\end{array}$ & $\begin{array}{c}290 \\
33 \\
2\end{array}$ & $\begin{array}{c}89.2 \\
10.2 \\
0.6\end{array}$ \\
\hline Educational status & $\begin{array}{l}\text { No education } \\
\text { Primary education } \\
\text { Secondary education } \\
\text { Above secondary education }\end{array}$ & $\begin{array}{c}153 \\
99 \\
47 \\
26\end{array}$ & $\begin{array}{c}47.1 \\
30.5 \\
14.5 \\
8\end{array}$ \\
\hline Forms of disability & $\begin{array}{l}\text { Deaf } \\
\text { Blind } \\
\text { Handcape upper limp } \\
\text { Handcape lower limp } \\
\text { Handcape both limp } \\
\text { Others }\end{array}$ & $\begin{array}{c}37 \\
58 \\
41 \\
128 \\
28 \\
33\end{array}$ & $\begin{array}{c}11.4 \\
17.8 \\
12.6 \\
39.4 \\
8.6 \\
10.2\end{array}$ \\
\hline Occupation & $\begin{array}{l}\text { Housewife } \\
\text { Student } \\
\text { Governmental employment } \\
\text { NGO } \\
\text { Merchant } \\
\text { Daily laborer } \\
\text { Local drink seller } \\
\text { Beggars }\end{array}$ & $\begin{array}{c}48 \\
66 \\
4 \\
7 \\
74 \\
41 \\
3 \\
82\end{array}$ & $\begin{array}{c}14.8 \\
20.3 \\
1.2 \\
2.2 \\
22.8 \\
12.6 \\
0.9 \\
25.2\end{array}$ \\
\hline Income & $\begin{array}{l}150-300 \text { ETB } \\
301-600 \text { ETB } \\
601-1000 \text { ETB } \\
\geq 1001 \text { ETB }\end{array}$ & $\begin{array}{c}147 \\
132 \\
39 \\
7\end{array}$ & $\begin{array}{c}45.2 \\
40.6 \\
12 . \\
2.2\end{array}$ \\
\hline
\end{tabular}

Income category is based on published literatures (10), "widowed and separated, "spinal bone deformation. Age categorization is based on EDHS 2011, ETB (Ethiopian birr). 
Table 2. Family planning characteristics of study individuals in Bahir Dar City, Amhara Region, North West Ethiopia August 2013.

\begin{tabular}{|c|c|c|c|}
\hline Variables & Categories & Frequency & Percentage \\
\hline Have you ever been pregnant & $\begin{array}{l}\text { 1. Yes } \\
\text { 2. No }\end{array}$ & $\begin{array}{l}139 \\
186\end{array}$ & $\begin{array}{l}42.8 \\
57.2\end{array}$ \\
\hline If yes, How many times have you been pregnant & $\begin{array}{l}1 .<5 \\
2 . \geq 5\end{array}$ & $\begin{array}{l}124 \\
201\end{array}$ & $\begin{array}{l}38.2 \\
61.8\end{array}$ \\
\hline Were all your pregnancies wanted & $\begin{array}{l}\text { 1. Yes } \\
\text { 2. No }\end{array}$ & $\begin{array}{l}89 \\
50\end{array}$ & $\begin{array}{l}27.4 \\
15.4\end{array}$ \\
\hline $\begin{array}{l}\text { If no, what was the reason you could not } \\
\text { avoid becoming pregnant }\end{array}$ & $\begin{array}{l}\text { 1. Lack of awareness } \\
\text { 2. Poor access } \\
\text { 3. Husband/partner disapproval } \\
\text { 4. Relative disapproval } \\
\text { 5. Contraceptive failure } \\
\text { 6. Religion prohibition } \\
\text { 7. Rape }\end{array}$ & $\begin{array}{c}19 \\
2 \\
10 \\
13 \\
2 \\
2 \\
2\end{array}$ & $\begin{array}{c}38 \\
4 \\
20 \\
26 \\
4 \\
4 \\
4\end{array}$ \\
\hline $\begin{array}{l}\text { If it was due to contraceptive method failure, } \\
\text { what was the method used }\end{array}$ & $\begin{array}{l}\text { 1. Pills } \\
\text { 2. Injectables } \\
\text { 3. Natural methods } \\
\text { 4. Other }\end{array}$ & $\begin{array}{l}7 \\
3 \\
2 \\
1\end{array}$ & $\begin{array}{c}53.8 \\
23.1 \\
15.4 \\
7.7\end{array}$ \\
\hline Are you currently pregnant & $\begin{array}{l}\text { 1.Yes } \\
\text { 2. No }\end{array}$ & $\begin{array}{c}9 \\
316\end{array}$ & $\begin{array}{c}2.8 \\
97.2\end{array}$ \\
\hline Desired number of children & $\begin{array}{l}1.1-2 \\
2 . \geq 3\end{array}$ & $\begin{array}{l}187 \\
138\end{array}$ & $\begin{array}{l}57.5 \\
42.5\end{array}$ \\
\hline $\begin{array}{l}\text { How long would you like to wait from now } \\
\text { before the birth of another child }\end{array}$ & $\begin{array}{l}\text { 1. Less than } 2 \text { years } \\
\text { 2. } 2 \text { to } 3 \text { years } \\
\text { 3. } 3 \text { to } 4 \text { years } \\
\text { 4. More than } 4 \text { years }\end{array}$ & $\begin{array}{l}20 \\
70 \\
19 \\
78\end{array}$ & $\begin{array}{c}6.2 \\
21.5 \\
5.8 \\
24\end{array}$ \\
\hline Did you give birth & $\begin{array}{l}\text { 1. Yes } \\
\text { 2. No }\end{array}$ & $\begin{array}{l}137 \\
188\end{array}$ & $\begin{array}{l}42.2 \\
57.2\end{array}$ \\
\hline If yes, how many live children do you have & $\begin{array}{l}\text { 1. }<4 \\
\text { 2. } \geq 4\end{array}$ & $\begin{array}{c}124 \\
14\end{array}$ & $\begin{array}{c}38.2 \\
4.3\end{array}$ \\
\hline
\end{tabular}

Number of pregnancy category is based on published literatures.

$4 \%$, mentioned as reasons for these unwanted pregnancies. Only $2.8 \%$ respondents were pregnant during the study period. Majority, 57.5\% of the study participants had a desire to have 1 - 2 children for the future. Seventy eight, $41.5 \%$ of respondents mentioned that they can wait more than four years till the next child. About $42.2 \%$ of the respondents had ever given birth and the 57.8\% didn't give birth. A larger proportion, $89.8 \%$ of the women had less than 4 children and $10.2 \%$ had no living children at the time of the study. About $94 \%$ of the participants had knowledge on family planning. Women were also asked whether they have any intention to use family planning services in the future. About $75.1 \%$ of respondents reported having the intention to use one of the family planning methods. Table 3 shows, only $36.9 \%$ of the respondents have ever used any method at the time of the survey and the majorities, $63.1 \%$ were non-users. Among those who are non user, the majority, $95.7 \%$ of the study participants didn’t want to use any method to delay or limit pregnancy. Among the list of family planning methods, Injection were the most frequently used, $61 \%$ followed by pills, $18.3 \%$, Norplant, 15.9\%, condom, 2.4\%, and Intra Uterine Contraceptive Device, 2.4\% while the remaining 5.21\% of respondents used other type of family planning methods. Regarding the purpose of using contraceptive, spacing were mentioned by majority of respondents, $70.7 \%$ and limiting $29.3 \%$ respectively. Table 4 shows, more than half, $52 \%$ of participants agreed and about, $26.5 \%$ of the study participants disagreed on existence of disability friendly reproductive health services. The reason for disagreement were inconvenience of services, $60.9 \%$, inappropriate information, $6.9 \%$ and inconvenience of institution, $18.4 \%$ were attributed to this reported poor disability friendily sexual and reproductive health services. With respect to sexual and reproductive health service outlet, $63.8 \%, 12.8 \%$ and $14 \%$ of the participants knew that they could get the products from governmental health facilities, private health facilities and family guidance association clinics, respectively.

Table 5 shows, age $>35$, low educational status and desired children greater than three were the independent 
Table 3. Product characteristics of study participants in Bahir Dar City, Amhara Region, North West Ethiopia, August 2013.

\begin{tabular}{|c|c|c|c|}
\hline Variables & Categories & Frequency & Percentage \\
\hline \multirow{2}{*}{$\begin{array}{l}\text { Have you ever used anything or tried in any } \\
\text { way to delay or avoid getting pregnant }\end{array}$} & Yes & 120 & 36.9 \\
\hline & No & 205 & 63.1 \\
\hline \multirow{2}{*}{$\begin{array}{l}\text { Did u want to use any method to delay or limit } \\
\text { pregnancy at that time }\end{array}$} & Yes & 120 & 60.9 \\
\hline & No & 77 & 39.1 \\
\hline \multirow{2}{*}{$\begin{array}{l}\text { Are you currently doing something or using any } \\
\text { method to delay or avoid getting pregnant }\end{array}$} & Yes & 82 & 25.2 \\
\hline & No & 243 & 74.8 \\
\hline \multirow{2}{*}{$\begin{array}{l}\text { Have you ever used modern contraceptives to } \\
\text { prevent pregnancy }\end{array}$} & Yes & 122 & 37.5 \\
\hline & No & 203 & 62.5 \\
\hline \multirow{2}{*}{ Are you currently using modern contraceptives } & Yes & 82 & 25.2 \\
\hline & No & 243 & 74.8 \\
\hline \multirow{5}{*}{ If yes, what type } & Pills & 15 & 18.3 \\
\hline & Condom & 2 & 2.4 \\
\hline & Injectables & 50 & 61 \\
\hline & Norplant & 13 & 15.9 \\
\hline & IUDs & 2 & 2.4 \\
\hline \multirow{5}{*}{ Why you prefer this method } & I have no choice & 11 & 13.4 \\
\hline & It is easy to use & 52 & 63.4 \\
\hline & It is for short period of time & 13 & 15.9 \\
\hline & Fear of side effect & 4 & 4.9 \\
\hline & Others & 2 & 2.4 \\
\hline \multirow{13}{*}{ If no, what were the reasons } & because I am pregnant & 3 & 2.4 \\
\hline & Not sexually active & 20 & 15.9 \\
\hline & Have less frequent sex & 2 & 1.6 \\
\hline & Husband/partner disapproval & 19 & 15.1 \\
\hline & Religious Prohibition & 2 & 1.6 \\
\hline & Lack of knowledge & 13 & 10.3 \\
\hline & fear of side effect & 40 & 31.7 \\
\hline & Difficult to obtain & 4 & 3.2 \\
\hline & Method was expensive & 1 & 0.8 \\
\hline & Too far & 2 & 1.6 \\
\hline & Preferred method is not available & 2 & 1.6 \\
\hline & I don’t want to use & 14 & 11.6 \\
\hline & Others & 4 & 3.2 \\
\hline \multirow{2}{*}{$\begin{array}{l}\text { If you are currently using the contraceptive } \\
\text { method for what purpose }\end{array}$} & Spacing birth & 58 & 70.7 \\
\hline & Limiting birth & 24 & 29.3 \\
\hline \multirow{3}{*}{$\begin{array}{l}\text { Is it easy or difficult for you to use } \\
\text { contraceptives }\end{array}$} & Easy & 196 & 60.3 \\
\hline & Difficult & 99 & 30.5 \\
\hline & Don’t know & 30 & 9.2 \\
\hline \multirow{11}{*}{ If difficult, why is it difficult } & Lack of money to buy & 6 & 6 \\
\hline & Lack of information & 47 & 47 \\
\hline & Pressure from sex partners & 6 & 6 \\
\hline & Religious prohibition & 3 & 3 \\
\hline & Difficult to find & 9 & 9 \\
\hline & Provider disapproves & 5 & 5 \\
\hline & Distribution places are inconvenient & 14 & 14 \\
\hline & Being afraid to buy from ops/pharmacy & 5 & 5 \\
\hline & Too far to find & 2 & 2 \\
\hline & Ignorance & 2 & 2 \\
\hline & Others & 1 & 1 \\
\hline \multirow{3}{*}{$\begin{array}{l}\text { Which group you belong regarding } \\
\text { contraceptive practice? }\end{array}$} & Current user & 75 & 23.1 \\
\hline & Ever used & 50 & 15.4 \\
\hline & Non user & 200 & 61.5 \\
\hline
\end{tabular}


Table 4. Health Service Provider characteristics of study participants in Bahir Dar town, Amhara Region, North West Ethiopia, August 2013.

\begin{tabular}{|c|c|c|c|}
\hline Variables & Categories & Frequency & Percentage \\
\hline \multirow{3}{*}{$\begin{array}{l}\text { Do you agree that existing SRH services } \\
\text { are disability friendly? }\end{array}$} & 1. Agree & 169 & 52 \\
\hline & 2. Disagree & 86 & 26.5 \\
\hline & 3.Unsure & 70 & 21.5 \\
\hline \multirow{7}{*}{$\begin{array}{l}\text { If you disagree, what is your main } \\
\text { reason? }\end{array}$} & 1. Service are not in accordance with PWDs need & 53 & 16.3 \\
\hline & 2. Information provided at the centers are not appropriate & 6 & 1.8 \\
\hline & 3. Providers fail to keep privacy and confidentiality & 1 & 0.3 \\
\hline & 4. Poor handling and scolding by health workers & 3 & 0.9 \\
\hline & 5.Too much waiting time to get the service & 2 & 0.6 \\
\hline & 6. The health institutions are inconvenient. & 16 & 4.9 \\
\hline & 7. Other & 6 & 1.8 \\
\hline \multirow{8}{*}{$\begin{array}{l}\text { What are the main obstacles that prevent } \\
\text { disabled from getting Sexual and } \\
\text { Reproductive Health services in health } \\
\text { institutions? }\end{array}$} & 1.Too far health institutions & 47 & 14.5 \\
\hline & 2. Too expensive services & 14 & 4.3 \\
\hline & 3. Providers fail to keep privacy and confidentiality & 7 & 2.2 \\
\hline & 4. Poor communication and handling by health worker & 10 & 3.1 \\
\hline & 5. Too much waiting time to get the service & 13 & 4.0 \\
\hline & 6. The health institutions are inconvenient. & 131 & 40.3 \\
\hline & 7. The health institutions are inconvenient. & 83 & 25.5 \\
\hline & 8. Don't know & 20 & 6.2 \\
\hline
\end{tabular}

Table 5. Association of variables with unmet need for family planning in Bahir Dar, Amhara, North West Ethiopia, August 2013.

\begin{tabular}{|c|c|c|c|c|c|}
\hline \multirow{2}{*}{ Variables } & \multirow{2}{*}{ Variable categories } & \multicolumn{2}{|c|}{$\begin{array}{c}\text { Unmet need } \\
\mathbf{n}=\end{array}$} & \multirow{2}{*}{$\begin{array}{c}\text { COR with } 95 \% \\
\text { confidence interval }\end{array}$} & \multirow{2}{*}{$\begin{array}{c}\text { AOR with } 95 \% \\
\text { confidence interval }\end{array}$} \\
\hline & & Yes & no & & \\
\hline \multirow{5}{*}{ Age } & $15-19$ & 8 & 16 & $0.64(0.16-2.66)$ & $0.5(0.09-3.24)$ \\
\hline & $20-24$ & 19 & 33 & $0.28(0.11-0.72)$ & $0.2(0.07-0.76)^{* *}$ \\
\hline & $25-29$ & 12 & 40 & $0.14(0.05-0.4)$ & $0.4(0.14-1.42)$ \\
\hline & $30-34$ & 13 & 18 & $0.35(0.13-0.92)$ & $1.9(0.31-12.6)$ \\
\hline & $\geq 35$ & 27 & 13 & 1.00 & 1.00 \\
\hline \multirow{4}{*}{ Educational status } & No education & 42 & 47 & $2(1.02-4.2)$ & $11.2(1.3-101.8)^{* *}$ \\
\hline & Primary education & 24 & 41 & $0.72(0.23-2.22)$ & $7.3(0.81-65.5)$ \\
\hline & Secondary & 4 & 21 & $0.23(0.05-1.11)$ & $0.9(0.07-11.3)$ \\
\hline & Above secondary & 9 & 11 & 1.00 & 1.00 \\
\hline \multirow{2}{*}{ Did you give birth } & Yes & 46 & 46 & $2.24(1.21-4.18)$ & $2.1(0.65-6.45)$ \\
\hline & No & 33 & 74 & 1.00 & 1.00 \\
\hline \multirow{3}{*}{ Easy or difficult to use FP } & Easy & 52 & 76 & $0.91(0.27-3.18)$ & $2.1(0.87-5.32)$ \\
\hline & Difficult & 21 & 36 & $0.78(0.21-2.98)$ & $6.9(1.29-36.87)$ \\
\hline & Don’t know & 6 & 8 & 1.00 & 1.00 \\
\hline \multirow{2}{*}{$\begin{array}{l}\text { Desired number of } \\
\text { children }\end{array}$} & $1-2$ & 36 & 81 & $0.4(0.23-0.74)$ & $0.2(0.09-0.47)^{* *}$ \\
\hline & $\geq 3$ & 43 & 39 & 1.00 & 1.00 \\
\hline \multirow{3}{*}{ Main obstacles } & Health institution related & 44 & 80 & 1.00 & 1.00 \\
\hline & Health service worker & 13 & 8 & $2.96(1.14-7.67)$ & $2.21(0.87-5.32)$ \\
\hline & Don’t know & 22 & 32 & $1.25(0.65-2.41)$ & $0.5(0.11-2.35)$ \\
\hline \multirow{2}{*}{$\begin{array}{l}\text { Were all pregnancies } \\
\text { wanted }\end{array}$} & Yes & 23 & 32 & 1.00 & 1.00 \\
\hline & No & 23 & 14 & $2.28(0.9-5.89)$ & $0.3(0.53-1.36)$ \\
\hline \multirow{2}{*}{$\begin{array}{l}\text { Why like to use FP for the } \\
\text { future }\end{array}$} & Spacing & 51 & 75 & $0.04(0.01-0.27)$ & $0.7(0.45-1.17)$ \\
\hline & Limiting & 19 & 1 & 1.00 & 1.00 \\
\hline
\end{tabular}

predictor variable for unmet need for family planning. The hosmer and lemeshow goodness test shows the model is fitted which was 0.994 .

According to this study the level of unmet need for family planning among women with disabilities was $24.3 \%$ 
which is in line with Amhara region findings, which is 22.1\% and Demographic health survey results for Ethiopia which is $25.3 \%$ [11] [12]. It is about nearly same as those of the Philippines, $22.3 \%$ and Cambodia, $16.6 \%$. While in china unmet need for family planning was $2.3 \%$ [13]. The discrepancy found between the study in china and this study might be due to one child policy of china and other socio-economic factors.

This study revealed that unmet need is specifically high among women who are 35 year and above which is about $67.5 \%$. Smaller Percentages in need of family planning were found in the age group of $25-29$ which is 23\%. In contrast the study conducted in Hawassa showed that unmet need is high in the age group of 25 - 29 and low in the age group of above 35 [14]. Based on the result of this study women with disabilities in the age group of 25 - 29 had 80\% less likely to have unmet need than women above 35 years old (AOR = 0.2, 95\% CI: 0.07 0.76), In contrast the study conducted at Enemay district, northwest Ethiopia stated that as age increased, the level of unmet need was decreased and age groups of married women 15 - 19, 20 - 24 and 25 - 29 were positively and significantly associated to unmet need for FP when compared to age group 34-39 with (AOR $=2.357$, 95\%CI: 1.689 - 5.691), (AOR = 2.630, 95\%CI: 1.347 - 8.262) and (AOR = 2.018, 95\%CI: 1.525 - 4.820) respectively [11]. This variation might be mostly due to women with disability has delayed to start sexual relationship.

According to this study the prevalence of unmet need among women who have no education is $47.2 \%$ is considerably higher than secondary education which is $16 \%$ which is in line with the study in Kenya [15]. This study also revealed that those women with disability who have no education were 11.2 times more likely to have unmet need than those who have secondary education (AOR = 11.2, 95\% CI: $1.3-101.8$ ), which is In consistent with the study at Hawssa showed that Women with primary education were 7 times more likely than women with higher education to have unmet need [14]. And the study at Butajira showed that married women who attained primary and secondary plus level of education have about 1.3 and 2 times less likely to have unmet need [9]. The study conducted in Kenya also showed that better educated women—secondary level or higher have considerably less unmet need which is $17 \%$ than women with little or no education that is $26 \%$ [15].

This study had also revealed that women's desire for $1-2$ children were $60 \%$ less likely to have unmet need than those who need to have greater than three children (AOR $=0.2$, 95\% CI: $0.09-0.47$ ). Unlike a study done in Enemay district northwest Ethiopia which showed no significant association between desired number of children and unmet need [11]. The discrepancy might be because of the difference in sampling technique (multistage), high sample size (770) and sampling design (comparative cross-sectional study design).

\section{Conclusions}

Based on the finding of the study we can conclude that, the overall magnitude of unmet need among women with disabilities was high. Women who are in the age group of $20-24$, women who have no education and women desire to have 1 - 2 children were independent predictor variables for unmet need for FP among women with disabilities.

Therefore based on the study findings and conclusion discussed above, the associations provide short term trainings in accordance with their age group. The local educational bureaus should also strive to increase the educational level of women with disabilities beyond primary level. Family guidance association should give adequate attention and trainings for women with disabilities and should also prepare awareness creation programs.

Further research should be conducted by increasing sample size and more geographic areas in order to identify the extent of the unmet need of women with disability in rural population.

\section{Competing Interests}

The authors declare that they have no computing interests.

\section{Authors' Contributions}

Abel Lule Tessema designed the study, organized data collection, analyzed the data, interpreted the data and prepare the manuscript.

Mekonnen Aycheluhem: Advised and led in designing the study, data collection, analysis and take much part in manuscript preparation. 
Tsion Samuel Bunare also assisted in designing the study, data collection, analysis and manuscript preparation.

\section{Acknowledgements}

The authors would like to express their heartfelt gratitude for the Joint MPH program, GAMBY college of medical sciences and Bahir Dar university without the support of these organizations this research work would not have been feasible. We also thank data collectors and participants for their willingness to participate and spent their precious time for the success of the study. The authors also thank Cheshire Ethiopia foundation and its field workers for their technical support during the study period.

\section{References}

[1] Hailemariam, A. and Haddis, F. (2011) Factors Affecting Unmet Need for Family Planning in Southern Nations Nationalities and Peoples Region, Ethiopia. Ethiopian Journal of Health Sciences, 21, 77-89. http://dx.doi.org/10.4314/ejhs.v21i2.69048

[2] USAID (2010) The Unmet Need for Contraception in the Developing World and the Former Soviet Union. Academic Article Journal from International Family Planning Perspectives, 28.

[3] Anthony, L.O., Joseph, U.O. and Emmanuel, M.N. (2009) Prevalence and Determinants of Unmet Need for Family Planning in Nnewi, South East Nigeria. International Journal of Medicine and Medical Sciences, 1, 325-329.

[4] Center for Reproductive Rights. Reproductive Rights and Women with Disabilities, 2002.

[5] USAID (2010) The Status of Family Planning in Sub-Saharan Africa.

[6] Kols, A. (2008) Reducing Unmet Need for Family Planning: Evidence Based Strategies and Approaches. Outlook, 25.

[7] Ashford, L. (2009) Unmet Need for Family Planning: Recent Trends and Their Implications for Program.

[8] USAID (2010) Three Successful Sub-Saharan African Family Planning Programs.

[9] Mekonnen, W. and Worku, A. (2011) Determinants of Low Family Planning Use and High Unmet Need in Butajera District, South Central Ethiopia. Bio Med., 2011.

[10] Ethiopian Center for Disability and Development (ECDD) in Collaboration with DKT (2012) Assessment of Sexual and Reproductive Health Products and Services Use by Persons with Disability.

[11] Getiye, D., Mekonnen, A. and Amanuel, A. (2013) Prevalence and Associated Factors of Unmet Need for Family Planning among Arried Women in Enemay District, Northwest Ethiopia. Global Journal of Medical Research, 13, 2930.

[12] Central Statistical Agency [Ethiopia] (2011) Ethiopia Demographic and Health Survey Addis Ababa, Ethiopia.

[13] World Health Organization (2013) Contraceptive Prevalence Rate, Total Fertility Rate, Unmet Need for Family Planning. WHO in the Western Pacific.

[14] Sahele, S. (2003) Assessment of the Magnitude and Determinants of Unmet Need for Family Planning among Currently Married Women in Urban and Periurban Community in Hawassa, Southern Ethiopia. Ethiopia Journal of health Science, 21, 68-70.

[15] NCAPD Policy Brief (2010) Fulfilling Unmet Need for Family Planning Can Help Kenya Achieve Vision. 
Scientific Research Publishing (SCIRP) is one of the largest Open Access journal publishers. It is currently publishing more than 200 open access, online, peer-reviewed journals covering a wide range of academic disciplines. SCIRP serves the worldwide academic communities and contributes to the progress and application of science with its publication.

Other selected journals from SCIRP are listed as below. Submit your manuscript to us via either submit@scirp.org or Online Submission Portal.
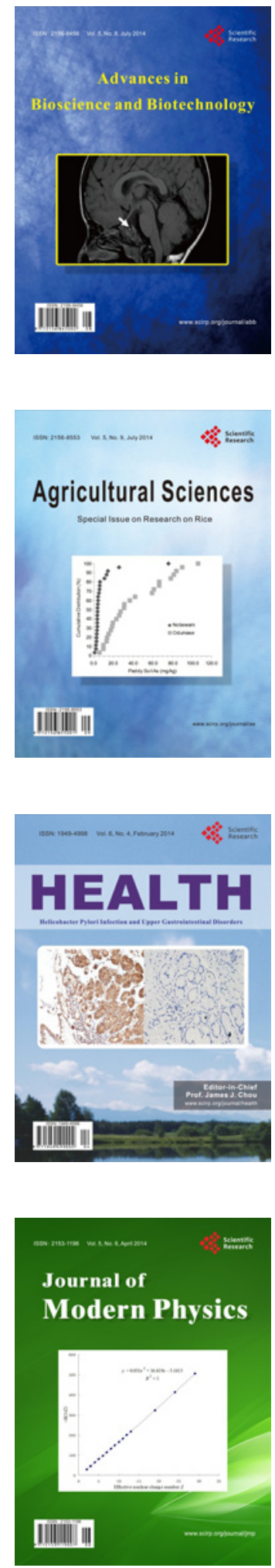
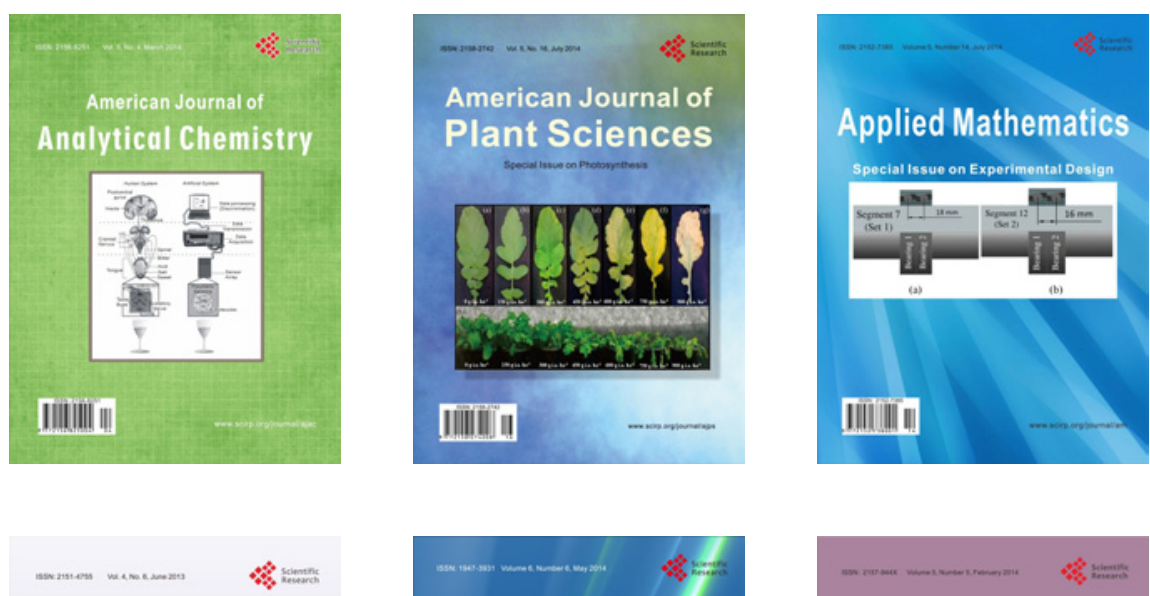

Creative Education
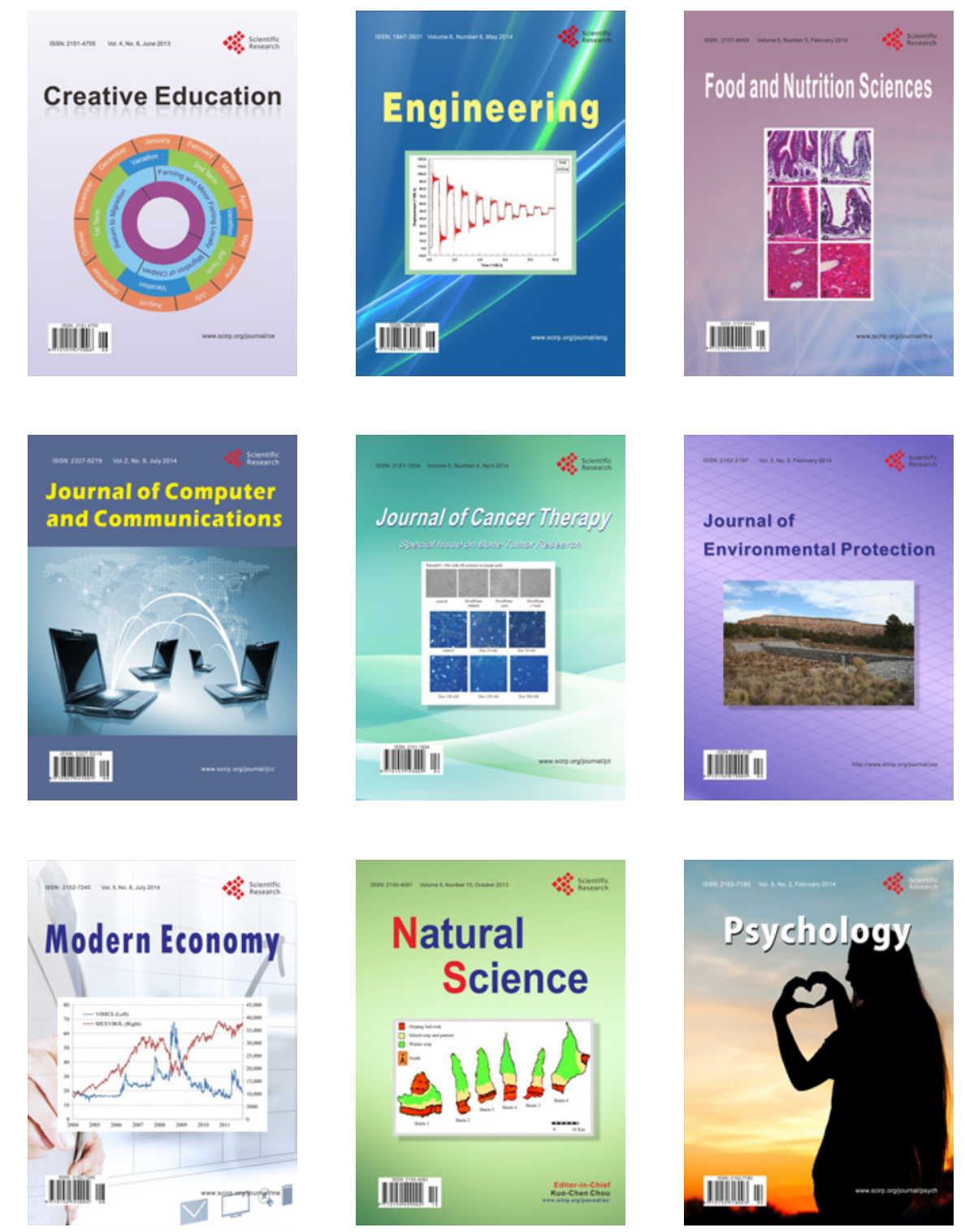